\title{
Pengembangan bahan ajar kode braille berbasis teori elaborasi bagi guru pendidikan khusus
}

\author{
Rendy Roos Handoyo \\ Fakultas Ilmu Pendidikan. Jl Colombo Nomor 1, Karangmalang, Yogyakarta, 55281, Indonesia \\ * Corresponding Author. E-mail: rendy.roos@uny.ac.id
}

\begin{abstract}
Abstrak: Penelitian ini bertujuan untuk menghasilkan produk bahan ajar kode Braille berbasis teori elaborasi bagi guru pendidikan khusus. Penelitian ini merupakan penelitian dan pengembangan model Borg and Gall yang mencakup 9 (sembilan) langkah kegiatan, yakni: mengumpulkan infromasi dan studi kebutuhan, perancangan, pengembangan produk awal, uji coba tahap awal, revisi, lapangan utama, revisi, lapangan operasional dan penyempurnaan produk. Pengumpulan data yang digunakan yaitu angket. Hasil penelitian yaitu buku tentang belajar Braille dengan elaborasi dilengkapi 6 (enam) modul di tiap jenjang kelas. Kriteria bahan ajar berdasarkan uji ahli media dengan kategori Sangat Layak, ahli materi dengan kategori Layak dan uji coba lapangan dengan kategori Sangat Layak.
\end{abstract}

Kata Kunci: bahan ajar, teori elaborasi, kode Braille, guru pendidikan khusus

\section{Developing elaborate theory-based teaching materials for braille codes for teachers of special education}

\begin{abstract}
The aim of this research is to produce elaborate theory-based teaching materials of braille codes for teachers of special education. This research was a research and development by Borg and Gall model covering nine activity steps, namely: gatheringinformation and studying the need, designing, initialling product development, trying early stage, revising, trying main field, revising, trying operational field and perfecting product. Data were collected by using questionaire. The result of the study are books about learn the Braille by elaborate with six moduls at every class. The product appropriateness based on media expert with Very Good, materials expert with Good and trying field with Very Good.
\end{abstract}

Keywords: teaching materials, elaborate theory, Braille code, special education teacher

\section{PENDAHULUAN}

Lewis, R.B dan Doorlag, D.H (2011, p.28) menyatakan bahwa guru pendidikan khusus memberikan layanan instruksional untuk siswa dengan kebutuhan khusus. Guru yang dimaksud memberikan layanan pendidikan khusus sesuai dengan hambatan dan kebutuhan yang diperoleh dari hasil asesmen. Salah satu anak yang perlu mendapatkan layanan pendidikan khusus yaitu anak tunanetra dengan pemberian baca tulis Braille dan pengembangan orientasi mobilitas serta komunikasi.

Kemampuan Braille adalah salah satu keterampilan dasar sebagai syarat seorang guru pendidikan khusus mencakup identifikasi secara benar terkait karakter Braille (Puttman, B \& Tiger, F 2015, p.127). Kompetensi guru pendidikan khusus untuk anak tunanetra antara lain: (1) competence in reading (guru mampu membaca teks dalam bentuk Braille), (2) competence in writing (guru dapat menulis teks secara tepat) dan (3) use of apropriate instructional method (guru menggunakan metode dan media pengajaran yang tepat) sesuai standar dan syarat guru bagi anak tunanetra dalam National Federation of the Blind. Kompetensi guru tersebut dapat ditingkatkan melalui pelatihan maupun penambahan wawasan pengetahuan tentang membaca dan menulis Braille.

Hasil temuan berdasarkan penelitian yang dilakukan oleh Sari Rudiyati (2010, p.15) menunjukkan empat puluh enam persen (46\%) guru bagi anak tunanetra memperoleh pedikat cukup (C) dan tiga puluh enam persen (36\%) mendapat predikat kurang $(\mathrm{K})$ sesuai standar nasional kompetensi guru di Indonesia. Data menunjukkan bahwa kompetensi guru pendidikan khusus dengan bidang keahlian pengajaran anak tunanetra masih tergolong rendah. Salah satu bagian yang perlu ditingkatkan oleh guru pendidikan khusus yaitu kompetensi pada aspek profesional. Pada kompetensi 


\section{JPK (J urnal Pendidikan Khusus), 14 (2), 2018 - 47}

Rendy Roos Handoyo

profesional terdapat kompetensi spesifik mengenai Braille. Kompetensi tersebut terbagi untuk mengetahui konsep dasar Braille dan mampu menerapkan konsep Braille dalam kegiatan pengembangan pembelajaran.

Faktanya, guru pendidikan khusus kesulitan mencapai kompetensi untuk memahami kode Braille, terampil menulis dan mengajarkan pada anak tunanetra. Kendala pertama yakni guru kesulitan menghafal kode-kode Braille tiap mata pelajaran karena memiliki kemiripan bentuk. Misalnya pada kode Bahasa Indonesia titik 1,4,5 adalah huruf "d”, namun untuk mata pelajaran matematika menjadi angka "4" dengan penambahan kode angka. Kesulitan guru dalam menghafal karena adanya perbedaan arah baca dan arah menulis kode Braille. Kegiatan yang dilakukan oleh guru sejauh ini yakni dengan membuat catatan kecil sederhana tentang kode Braille.

Kendala kedua terkait keterampilan guru pendidikan khusus untuk menulis Braille. Guru mengalami kesulitan untuk menentukan titik dalam membuat kode Braille karena terbatasnya sumber referensi tentang cara penulisan kode Braille. Kegiatan antisipasi yang dilakukan oleh guru yaitu membuat catatan khusus tentang kode Braille dalam arah baca dan arah tulis. Kesulitan guru pendidikan khusus dalam menghafal kode Braille berdampak dalam proses pembelajaran bagi anak tunanetra. Lemahnya penguasaan guru dalam menulis Braille berakibat pada kesalahan penulisan buku Braille yang digunakan dalam pembelajaran. Buku yang dicetak Braille tidak dapat terbaca oleh anak tunanetra karena kode-kode huruf dalam buku cetak tidak sesuai dengan kaidah penulisan Braille yang ada, khususnya untuk lambang-lambang matematika dan tanda baca.

Permasalahan lain ditemukan dalam struktur buku sistem Braille Indonesia yang sulit memberikan pemahaman bagi guru. Sistem Braille Indonesia tersusun untuk tiap bidang mata pelajaran (Bahasa Indonesia, Matematika, Kimia, Fisika). Bahasa yang digunakan cenderung formal dengan ukuran huruf kecil dan rapat. Akibatnya membuat mata pembaca mudah lelah dan kurang menarik minat baca. Di samping itu, sistem Braille Indonesia terbitan Depdiknas tidak dilengkapi dengan cara penulisan dan kaidah baca tulis yang disertai contoh. Tidak adanya latihan soal dan kunci jawaban untuk menulis serta membaca kode Braille menyebabkan guru mengalami kesulitan untuk mengukur kemampuan tentang pemahaman konsep tentang kode Braille. Buku tidak disertai dengan alat evaluasi sehingga guru kurang memiliki pengetahuan tentang variasi bentuk penilaian yang dapat diterapkan pula pada anak tunanetra.

Berdasarkan analisis dokumen, lima aspek kekurangan buku sistem Braille Indonesia terbitan Depdiknas meliputi isi, bahasa, tampilan, tata letak dan pengemasan. Isi buku sistem Braille Indonesia tidak tersusun secara terstruktur mengikuti Kompetensi Dasar tiap mata pelajaran bagi anak tunanetra. Misalnya pada sistem Braille Indonesia bidang Matematika terdapat 690 kode, namun simbol tanda angka ditulis pada urutan nomor 30. Di samping itu, tanda operasi penjumlahan dan pengurangan ditemukan pada urutan 67 dan 68 sedangkan tanda logaritma $(\log )$, akar $(\sqrt{ })$, pemangkatan $\left(\mathrm{x}^{2}\right)$ berada lebih awal di urutan 56,57,58. Kompetensi dasar anak tunanetra kelas 1 tingkat dasar pada mata pelajaran matematika diawali dengan pengenalan tanda angka, penjumlahan $(+)$, pengurangan $(-)$ dan sama dengan (=). Akibat penyusunan kode Braille yang tidak terstruktur, guru kesulitan mencari simbol sesuai materi pembelajaran tiap jenjang kelas.

Berdasarkan uraian permasalahan di atas, diketahui bahwa keterampilan menghafal, membaca dan menulis kode Braille perlu dikuasai oleh guru pendidikan khusus. Keterampilan tersebut sesuai dengan standar kualifikasi akademik dan profesional guru pendidikan khusus (Permendiknas Nomor 32 tahun 2008). Pengembangan sumber bahan ajar bagi guru digunakan untuk memahami konsep kode Braille mata pelajaran Bahasa Indonesia, Matematika dan IPA. Pengembangan yang dilakukan yakni bahan ajar berbasis teori elaborasi dalam bentuk buku cetak. Bruner, J (1960, p.41) menyatakan bahwa pengajaran dalam bentuk buku dengan sistem elaborasi merupakan tahapan efektif untuk menyajikan bahan ajar yang mudah dipelajari bagi guru. Guru pendidikan khusus disini dimaksudkan untuk guru di SLB maupun SD inklusi. Teori elaborasi memiliki komponen antara lain urutan elaborative, rangkuman, sintesis, analogi dan pengaktif strategi kognitif.

Bahan ajar yang dikembangkan mempertimbangkan arah baca dan arah tulis yang disajikan dalam gambar menarik sehingga membantu guru untuk menghafal kode Braille secara visual. Bahan ajar yang dirancang terdiri dari lima bagian utama meliputi peta kompetensi dasar, sejarah huruf Braille, pemahaman urutan pembentukan kode Braille, teknik pengajaran baca tulis Braille serta latihan soal. Penyajian didasarkan pada pendapat Merril dan Twitchell (1994, p.79) bahwa elaborasi mengikuti urutan dari pemahaman umum menuju bagian terperinci dari tahapan yang dipelajari 
sebagai bentuk hirarki berdasarkan tahapan analisis tugas milik Gagne. Urutan yang disajikan dimulai dari 5 titik Braille secara pijakan awal dalam memahami kode Braille. Langkah pengorganisasian teori elaborasi dimulai dengan kerangka isi, struktur yang memuat bagian-bagian yang paling penting sebagai persyaratan dari bidang studi tertentu(Made Wena, 2009, p.30).

Kelebihan bahan ajar yang dikembangkan didasarkan pada tiga tahapan perkembangan intelektual teori Bruner yakni enactive, iconic dan symbolic (Smith, M.K, 2010, p.116). Prinsip ketiga tahapan tersebut disajikan untuk memberikan pemahaman konkret mengenai definisi dan bentuk kode Braille melalui gambar serta aktivitas membaca maupun menulis sehingga mudah diingat. Bahan ajar berisi latihan disertai contoh. Latihan yang diberikan sebagai penguatan untuk mempertahankan retensi (daya ingat) melalui tinjauan kembali tentang kode Braille (Made Wena, 2009, p.28). Bagian keempat, berisi tentang evaluasi pemahaman kode Braille untuk mengukur tingkat penguasaan kode Braille tiap mata pelajaran.

\section{METODE}

Penelitian ini menggunakan pendekatan kuantitatif dengan penelitian dan pengembangan adaptasi model Borg and Gall. Langkah kegiatan mencakup 9 (sembilan) aktivitas meliputi: identifikasi dan studi kebutuhan, perancangan, pengembangan produk awal, uji coba tahap awal, revisi, uji coba lapangan utama, revisi, uji coba lapangan operasional dan penyempurnaan produk.Pendekatan yang digunakan dalam penelitian ini adalah pendekatan kualitatif. Untuk mewujudkan pemahaman mendalam mengenai fenomena apa yang dialami oleh subjek, peneliti menggunakan metode kualitatif dengan pendekatan studi kasus. Pendekatan studi kasus merupakan fenomena khusus yang hadir dalam suatu konteks yang terbatasi (bounded context), meski batas antara fenomena dan konteks tidak sepenuhnya jelas.

Subjek penelitian merupakan guru pendidikan khusus yang bekerja di sekolah luar biasa (SLB) dan sekolah penyelenggara pendidikan inklusif di Yogyakarta. Subjek penelitian berjumlah 56 guru yang terdiri dari 28 guru SLB dan 28 guru sekolah umum. Data yang dikumpulkan berupa kuantitatif dan kualitatif. Data kuantitatif diperoleh melalui pengisian angket dan data kualitatif diperoleh melalui wawancara dalam kuesioner.

Prosedur penelitian mengadaptasi langkah penelitian dan pengembangan Borg and Gall yang terangkum dalam tiga aktivitas berupa pendefinisian, perancangan dan pengembangan. Pada kegiatan pendefinisian, aktivitas yang dilakukan oleh peneliti yakni melakukan analisis empirik dengan studi lapangan dan analisis teoritik. Pada kegiatan perancangan, peneliti menyusun draft produk awal dan melakukan uji ahli kepada ahli materi terkait Braille dan ahli media untuk menilai pengemasan bahan ajar. Pada kegiatan pengembangan, peneliti melakukan uji coba lapangan tahap awal, utama dan operasional. Tiap ujicoba diakhiri dengan revisi. Aktivitas terakhir yakni penyempurnaan produk. Prosedur penelitian yang dilakukan oleh peneliti dapat dilihat dalam gambar berikut.

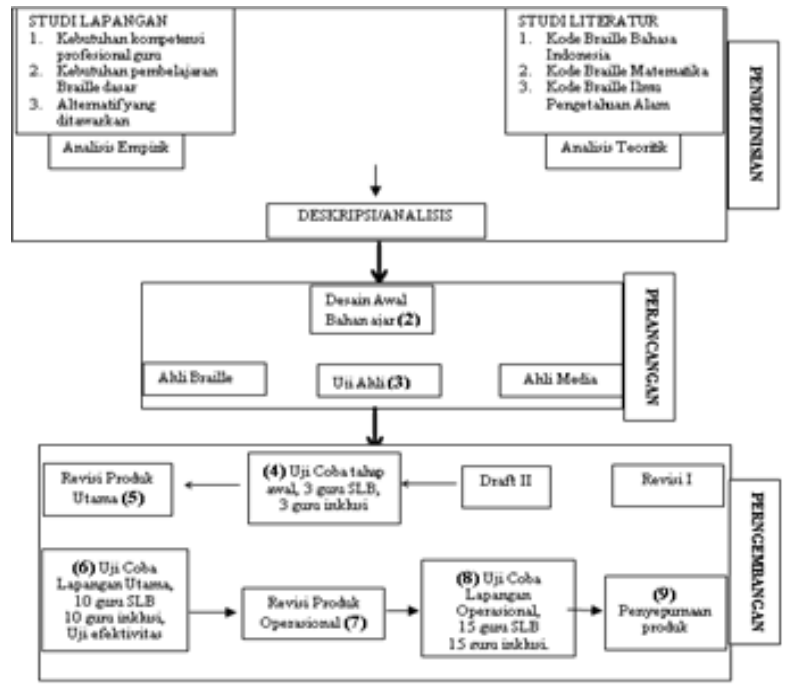

Gambar 1. Prosedur Penelitian 


\section{J PK (J urnal Pendidikan Khusus), 14 (2), 2018 - 49}

Rendy Roos Handoyo

Analisis data yang digunakan berupa deskriptif kuantitatif. Aktivitas yang dilakukan oleh peneliti untuk menganalisis data yakni: 1 . Menghitung skor rata-rata uji ahli dan uji coba lapangan, 2. Menetapkan kriteria kelayakan produk, 3. Mengolah data kualitatif dari pengisian kuesioner, 4. Menyajikan data dalam bentuk grafik dan dideskripsikan secara naratif, 5. Menarik kesimpulan.

\section{HASIL DAN PEMBAHASAN}

Pengembangan bahan ajar berbasis teori elaborasi terbagi dalam tiga tahapan yakni pendefinisian, perancangan dan pengembangan. Pendefinisan dilakukan melalui studi pustaka tentang buku Braille dan wawancara kepada guru pendidikan khusus. Data yang terkumpul digunakan untuk merancang bahan ajar sesuai hasil pendefinisian. Rancangan bahan ajar selanjutnya dilakukan pengujian kelayakan kepada ahli media dan materi Braille. Bahan ajar dikatakan layak dan dapat dilakukan pengembangan melalui uji kelompok kecil dan besar.

\section{Pendefinisian}

Data yang diperoleh selama studi pustaka Sistem Braille Indonesia terbitan tahun 2000 dan literatur terkait Braille dapat diketahui bahwa: a) Konsep memahami dan menghafal kode Braille berada di kelas satu, b) Penghafalan kode Braille dilakukan melalui tiga langkah pengelompokkan untuk huruf abjad, b) Satu kode dapat berfungsi menjadi kode lain dengan penambahan tanda khusus, c) Terdapat persamaan kode dengan simbol pada huruf awas, misal "FPB" ditulis dengan "FPB" dalam tulisan Braille, d) kode-kode dalam Bahasa Indonesia, Matematika dan IPA menempati letak titik yang saling berlawanan dengan bentuk kode serupa misalnya titik "1 huruf a" dan titik "4 tanda @”, e) kode IPA mulai muncul di kelas 5. Materi Bahasa Indonesia meliputi huruf abjad, tanda baca dalam kalimat, surat resmi dan cerita. Materi Matematika meliputi bilangan, tanda angka, tanda operasi hitung bilangan, geometri, pengukuran, jarak dan perbandingan. Materi IPA meliputi rumus gaya, tekanan, debit dan reaksi unsur sederhana. Pemberian cara mengajarkan baca tulis pada anak tunanetra agar tepat dan tulisan rapi. Ditambahkan pula sejarah dan penemu Braille sehingga menjadi wawasan bagi guru maupun anak tunanetra sebagai penghargaan sebagai penemu huruf Braille.

Guru menghendaki adanya hand out atau buku tentang ringkasan kode Braille yang dapat dipelajari secara mudah. Kemudahan untuk mengerti tata cara membaca, menulis dan menghafal kode. Guru menyarankan adanya buku saku atau media yang ringkas tetapi padat materi dengan dilengkapi ilustrasi gambar penjelas. Isi buku diharapkan memberikan tampilan cara menulis dan membaca kode Braille secara bersamaan dalam satu halaman. Setiap penjelasan kode disertai contoh penulisan dan membaca sehingga lebih memudahkan guru dalam memahami kode Braille. Di sisi lain, guru memiliki rasa ingin tahu tentang sejarah munculnya huruf Braille. Perlu ditambahkan pula cara mengajarkan baca tulis Braille bagi tunanetra awal.

Kode Braille yang ditampilkan hendaknya berwarna sehingga guru lebih mudah dalam mempelajari. Bentuk titik Braille berukuran besar sehingga terlihat jelas antara titik yang dibaca dengan titik yang tidak perlu dibaca. Warna huruf yang hampir sama dikelompokkan berdasarkan warna. Huruf untuk penjelasan dan contoh diharapkan dapat terbaca jelas oleh guru. Sampul bahan ajar dirancang lebih menarik dan disertai gambar sehingga guru lebih berminat untuk belajar Braille. Adapun rancangan produk bahan ajar berbasis teori elaborasi sebagai berikut:

1. Rangkaian urutan kompetensi menyajikan isi keseluruhan materi bahan ajar dalam peta kompetensi. Pada bagian ini menampilkan rangkaian kompetensi dalam mata pelajaran Matematika, Bahasa Indonesia dan IPA sampai syarat paling dasar yakni lima huruf abjad utama.

2. Urutan prasyarat belajar menampilkan keterampilan-keterampilan yang perlu dikuasai oleh guru pendidikan khusus sebelum menggunakan bahan ajar.

3. Rangkuman digunakan untuk menyajikan isi materi bahan ajar terkait kode Braille membaca, menulis, simbol dan lambang dalm huruf awas di bagian akhir bahan ajar.

4. Pesintesis ditampilkan melalui kategori kode Braille yang saling berkaitan antara bidang Bahasa Indonesia, Matematika dan IPA melalui teknik pencerminan maupun penurunan kode dalam bentuk penjelasan.

5. Analogi, digunakan untuk memudahkan guru pendidikan khusus menghafal kode Braille melalui perumpamaan gambar layar "TV".

6. Pengaktif kognitif digunakan melalui sajian materi kode Braille dalam bentuk pencerminan dan penurunan kode. 
7. Kontrol kognitif digunakan untuk mengukur kemampuan guru pendidikan khusus setelah menggunakan bahan ajar berbasis teori elaborasi melalui latihan soal.

\section{Perancangan}

Proses pengembangan bahan ajar ini menggunakan seperangkat alat yang digunakan, antara lain software pengolah gambar (Corel draw 5), software pengolah kata (Microsoft Word) dan software pengolah simbol Braille (MiBee Braille Converter). Corel draw digunakan untuk mendesain sampul modul. Microsoft Word digunakan untuk menjelaskan konsep, fakta dan atribut mengenai kode Braille. MiBee Braille Converter digunakan untuk membuat contoh-contoh penulisan baca tulis dalam bentuk Braille. Pengembangan bahan ajar ini mengacu pada analisis kompetensi dasar siswa tunanetra jenjang SD yang dilakukan oleh peneliti dan arahan dari ahli materi Braille. Prinsip teori elaborasi yang digunakan dalam mengembangkan bahan ajar meliputi simbol pembentukan kode Braille utama (a, b, c, d, e) menjadi gambar tulisan "TV", pencerminan kode serta penurunan letak titik memudahkan guru untuk memahami dan mengingat kode Braille.

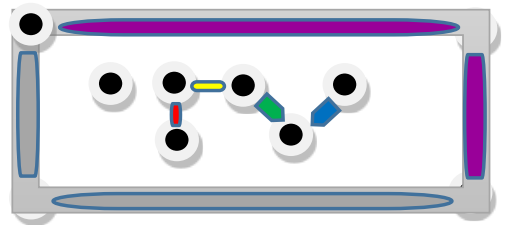

Gambar 2. Rancangan Pembentukan Simbol "TV”

Perhatikan titik-titik di keempat sudut yang membentuk sebuah bangun persegi panjang seperti layar televisi. Kemudian perhatikanlah titik-titik yang ada di dalam layar, apabila disambung dengan garis maka akan terbentuk menjadi huruf T dan V. Pada dasarnya sepuluh abjad kelompok pertama sudah dapat membentuk gambar layar TV tersebut. Namun untuk memudahkan menghafalkan, kita cukup menghafal kelima huruf abjad utama.

Pengorganisasian pesan dalam bahan ajar ini dikembangkan berbasis teori elaborasi yang disusun dengan mempertimbangkan prasyarat belajar, penguraian kompetensi ke sub-sub kompetensi untuk melihat persamaan kode sehingga menghasilkan lima huruf abjad utama kode Braille. Pemenggalan prasyarat kompetensi ditampilkan dalam pemetaan kompetensi sehingga memudahkan guru untuk belajar dan memahami muatan isi bahan ajar. Hal ini dibuktikan dengan hasil post tes subjek yang mengalami kenaikan setelah mempelajari bahan ajar selama tiga hari.

Proses pengembangan bahan ajar ini mengikuti tahap-tahap sesuai model Borg and Gall dan telah selesai divalidasi oleh ahli materi maupun ahli media. Berdasarkan ahli materi dan ahli media, bahan ajar ini layak digunakan sebagai sumber belajar bagi guru. Produk ini dapat digunakan sebagai alat bantu bagi guru pendidikan khusus untuk:1) memahami kode-kode huruf Braille mata pelajaran Bahasa Indonesia, Matematika, IPA; 2) menghapal kode-kode huruf Braille dengan mudah, 3) mengerti cara mengajarkan baca tulis Braille dengan teknik yang benar.

\section{Pengujian Ahli Materi I}

Penilaian produk bahan ajar dari ahli materi I memberikan komentar bahwa bahan ajar ini dapat membantu guru yang belum memahami atau belajar Braille dasar dan contoh yang disajikan mudah untuk dimengerti. Ahli materi I memberikan saran untuk melakukan revisi produk. Adapun saran dari ahli materi I yaitu: 1) menambahkan kata penjelas untuk tanda dalam kode Braille, 2) memperhatikan penulisan kode huruf Braille dalam evaluasi diri, 3) perbaikan gambar pada kode Matematika 4) membuat rangkuman menjadi empat tabel ke samping berisi tanda huruf, simbol, kode baca dan kode menulis. Hasil uji ahli materi I dapat dilihat pada tabel berikut.

Tabel 1. Hasil Uji Ahli Materi I

\begin{tabular}{clcc}
\hline No. & \multicolumn{1}{c}{ Aspek Penilaian } & Skor Rerata & Kategori \\
\hline 1. & Kelayakan Penyajian & 3,63 & Layak \\
2. & Kebahasaan & 4,00 & Layak \\
3. & Konsep Kode Braille & 4,00 & Layak \\
4. & Penerapan Teori Elaborasi & 3,88 & Layak \\
& Jumlah & $\mathbf{1 5 , 5 1}$ & \\
& Rata-rata & $\mathbf{3 , 8 8}$ & Layak \\
\hline
\end{tabular}




\section{Pengujian Ahli Materi II}

Penilaian produk bahan ajar dari ahli materi II memberikan komentar bahwa bahan ajar ini dapat digunakan oleh guru pendidikan khusus yang memenuhi prasyarat dan memiliki kelebihan untuk menanamkan konsep kode Braille bagi pemula karena mudah diingat. Guru yang tidak memenuhi prasyarat seperti contoh mengalami kendala dalam visual spasial akan kesulitan mempelajari bahan ajar ini. Ahli materi II memberikan saran untuk melakukan revisi produk. Adapun saran dari ahli materi II yaitu: 1) Mengembangkan kode Braille untuk tingkat lanjut, 2) Memperhatikan penulisan dengan MiBee Braille Converter karena ada beberapa titik tidak muncul, 3) Cermati penulisan dalam kode Matematika untuk bangun dan delta, 4) Kurangi kode-kode IPA karena belum diajarkan untuk jenjang SD. Hasil penilaian uji ahli materi II dapat dilihat dalam tabel berikut.

Tabel 2. Hasil Uji Ahli Materi II

\begin{tabular}{cccc}
\hline No. & \multicolumn{1}{c}{ Aspek Penilaian } & Skor Rerata & Kategori \\
\hline 1. & Kelayakan Penyajian & 4,09 & Layak \\
2. & Kebahasaan & 4,00 & Layak \\
3. & Konsep Kode Braille & 3,67 & Layak \\
4. & Penerapan Teori Elaborasi & 4,00 & Layak \\
& Jumlah & $\mathbf{1 5}, \mathbf{7 6}$ & \\
& Rata-rata & $\mathbf{3 , 9 4}$ & Layak \\
\hline
\end{tabular}

Penilaian dari ahli materi I dan II memberikan skor masing-masing 3,88 dan 3,94 dengan kategori Layak. Kelayakan isi penyajian bahan ajar diberikan nilai layak karena sajian materi sistematis, informasi kode Braille disajikan secara jelas antara cara membaca maupun menulis, mencantumkan informasi tentang metode cara menghafal serta pengajaran baca tulis Braille dan dilengkapi dengan variasi soal latihan. Di samping itu, sajian kode Braille, informasi penjelas, cara membaca dan menulis ditampilkan dalam satu halaman sehingga memudahkan guru pendidikan khusus sebagai pengguna untuk mempelajari. Hal ini sesuai dengan kriteria kelayakan isi dan penyajian bahan ajar menurut Chomsin Widodo (2008, p.67), Atwi Suparman (2014, p.321). dan Harjanto (2011, p.222).

\section{Pengujian Ahli Media I}

Penilaian produk bahan ajar dari ahli media I memberikan komentar bahwa bahan ajar ini dapat membantu guru untuk memahami cara menulis dan membaca kode Braille karena "simpel”, mudah dipahami dan ada ilustrasi yang jelas. Ahli media I memberikan saran untuk melakukan revisi produk. Adapun saran dari ahli media I yaitu: 1) Membuat rangkuman yang lebih jelas, 2) Komposisi warna lebih dikontraskan, 3) Perbaiki tahapan kompetensi dan subkompetensi, 4) Cermati posisi titik-titik Braille agar tidak terjadi kesalahan. Hasil uji ahli media I dapat dilihat dalam tabel berikut.

Tabel 3. Hasil Uji Ahli Media I

\begin{tabular}{cccc}
\hline No. & \multicolumn{1}{c}{ Aspek Penilaian } & Skor Rerata & Kategori \\
\hline 1. & Kelayakan Penyajian & 4,55 & Sangat Layak \\
2. & Kebahasaan & 4,60 & Sangat Layak \\
3. & Ketepatan Kompetensi & 4,75 & Sangat Layak \\
4. & Penerapan Teori Elaborasi & 4,63 & Sangat Layak \\
& Jumlah & $\mathbf{1 8 , 5 3}$ & \\
& Rerata & $\mathbf{4 , 6 3}$ & Sangat Layak \\
\hline
\end{tabular}

\section{Pengujian Ahli Media II}

Ahli media memberikan masukan bahwa sampul buku belum memberikan muatan pesan utama yang akan ditampilkan, tampilan isi terlalu sempit secara pewarnaan dan warna huruf kurang bervariasi. Pengujian dilakukan selama tiga kali dengan hasil berikut. 


\section{J PK (J urnal Pendidikan Khusus), 14 (2), 2018 - 52}

Rendy Roos Handoyo

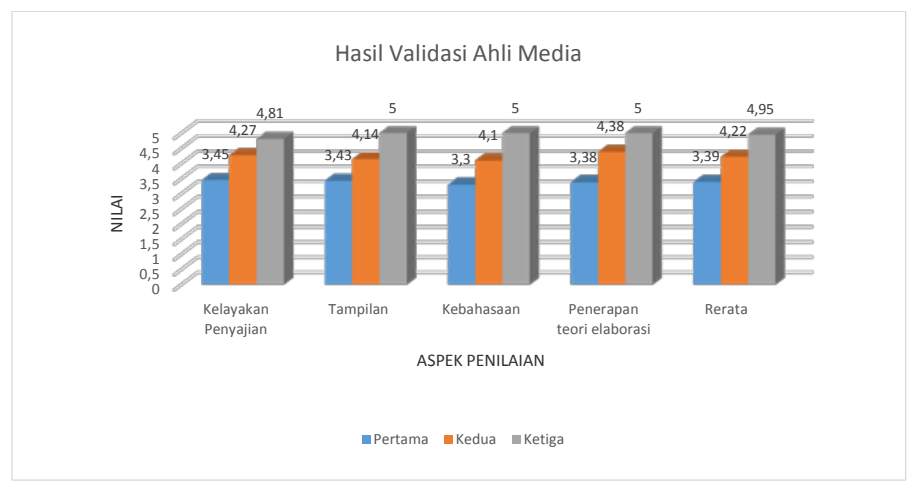

Gambar 3. Hasil Pengujian Ahli Media

Karakteristik dari bahan ajar berbasis teori elaborasi hasil pengembangan ini memiliki beberapa keunggulan. Keunggulan tersebut antara lain: 1) penyajian materi didukung dengan gambar-gambar yang memudahkan guru untuk mengingat, 2) adanya sajian gambar dan huruf yang bervariasi membuat bahan ajar ini menarik serta menimbulkan minat baca, 3) bahan ajar ini menampilkan caracara mudah untuk menghapal kode dengan pencerminan dan penurunan kode huruf Braille, 4) bentuk kode huruf Braille posisi baca dan menulis ditampilkan bersamaan dalam satu halaman sehingga memudahkan guru untuk memahami, 5) disusun sesuai dengan langkah-langkah menyusun bahan ajar yang baik, 6) bahan ajar berbentuk cetak sehingga mudah digunakan oleh guru, 7) dapat digunakan sebagai sumber belajar secara mandiri maupun kelompok gugus.

\section{Ujicoba Produk}

Ujicoba tahap awal dilakukan dengan 6 subjek yang terdiri dari 3 guru SLB dan 3 guru sekolah umum. Adapun saran untuk perbaikan produk yaitu: 1.Penggunaan pencerminan dapat mempermudah dalam menghafal kode Braille, 2.Materi yang disajikan secara runtut sehingga mudah memahami, 3.Penggunaan banyak gambar sehingga lebih menarik, 4.Gambar yang disajikan perlu ditambah dengan keterangan, 5.Penjelasan metode "Layar TV" kurang jelas dan 6. Evaluasi yang diberikan belum menggambarkan keseluruhan materi.

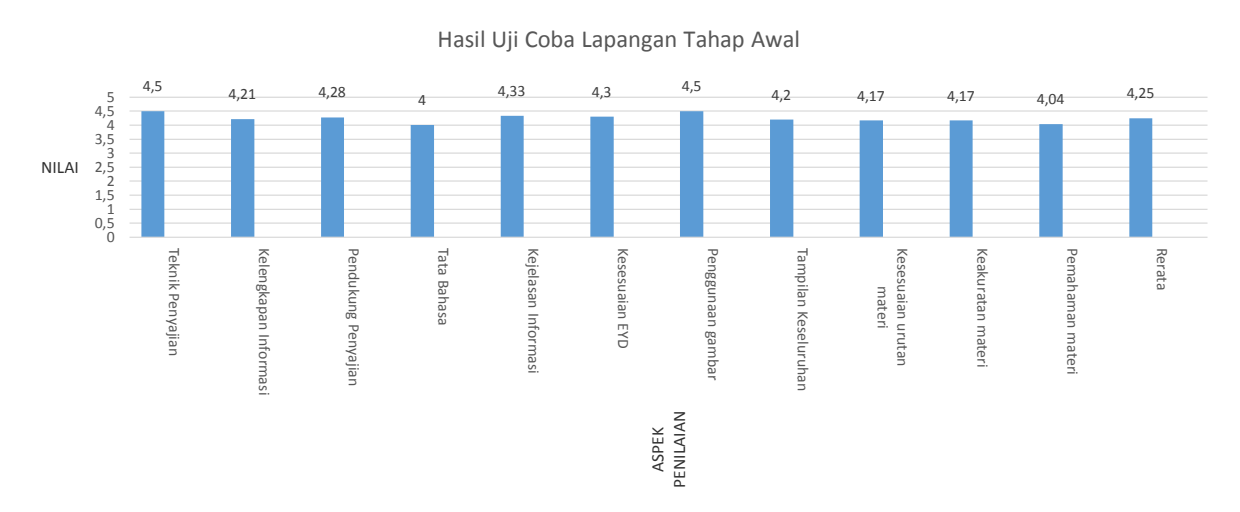

Gambar 4. Ujicoba Tahap Awal

Berdasarkan uji coba lapangan utama, 20 guru sebagai responden memberikan komentar dan saran untuk perbaikan produk. Adapun komentar positif terhadap produk yang dikembangkan yakni: 1. Penghafalan lebih mudah dengan rumus praktis, 2. Penjelasan disertai gambar yang jelas, 3. Materi disajikan runtut sehingga mudah memahami, 4. Penjelasan pada beberapa gambar terlalu panjang, 5. Font diperbesar sedikit dan bervariasi dan 6. Penggunaan warna beberapa huruf belum terlalu jelas. Data ujicoba lapangan utama dapat dilihat dalam grafik berikut. 


\section{JPK (J urnal Pendidikan Khusus), 14 (2), 2018 - 53}

Rendy Roos Handoyo

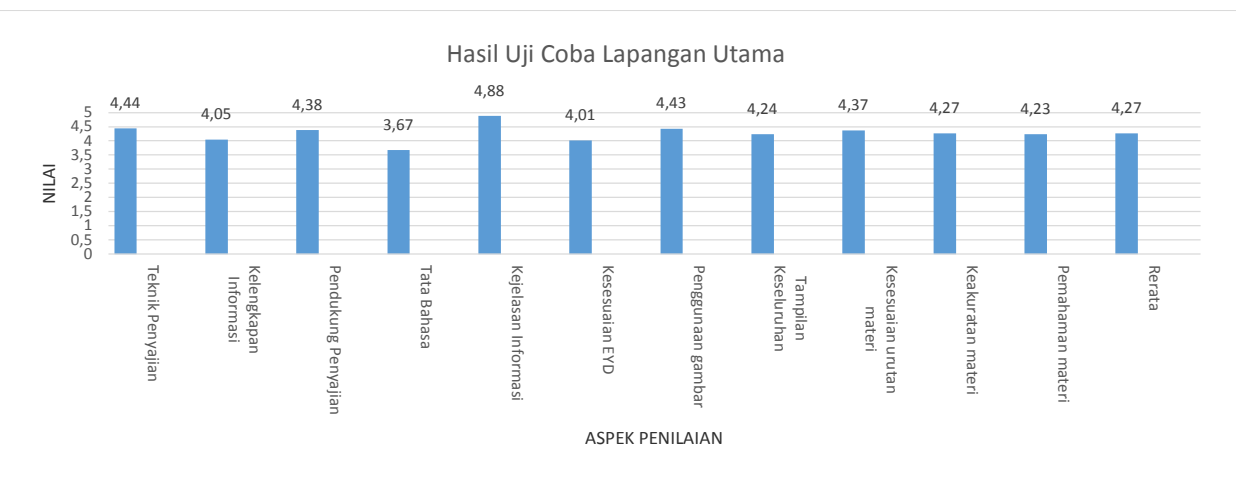

Gambar 5. Hasil Ujicoba Lapangan Utama

Berdasarkan uji coba lapangan operasional, 30 guru sebagai responden memberikan komentar dan saran untuk perbaikan produk. Adapun masukan terhadap produk yang dikembangkan yaitu: 1 . Penyajian warna huruf dan gambar menarik, 2. Pemberian sejarah huruf Braille menjadi tambahan pengetahuan, 3. Materi disajikan runtut sehingga mudah memahami, 4. Terdapat cara-cara mudah untuk menghafal kode, 5. Gambar pada teknik mangold kurang rapi, 6. Font diperbesar sedikit untuk rumus akar dan perpangkatan, 7. Penggunaan warna "MODUL" pada bagian sampul lebih dikontraskan. Saran yang diberikan oleh responden secara umum yaitu memberikan kontras warna antara background dan huruf serta memperbaiki gambar pada bagian teknik mangold.

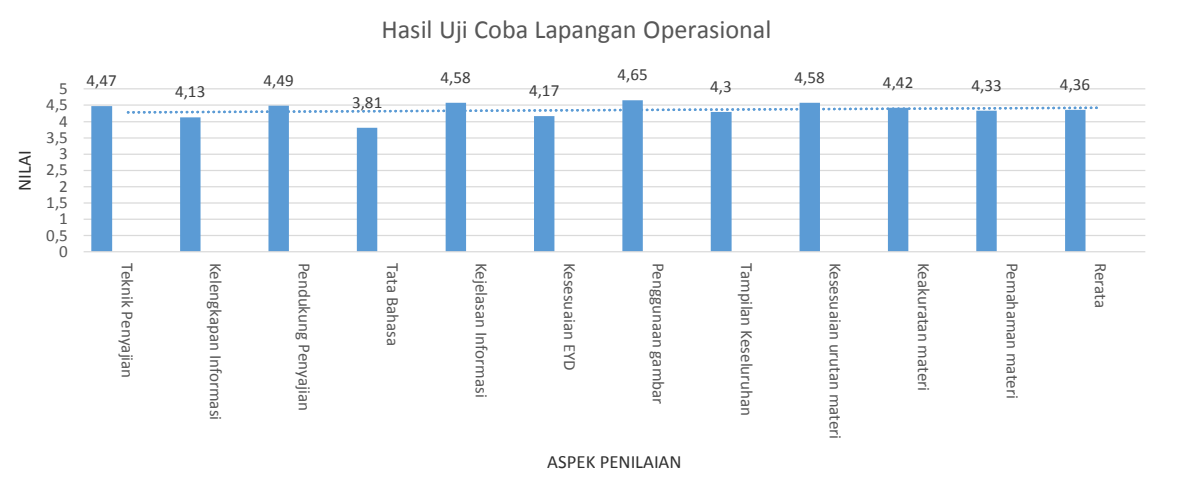

Gambar 6. Hasil Ujicoba Lapangan Operasional

Penilaian dari subjek dalam uji coba lapangan tahap awal, uji coba lapangan utama dan operasional memberikan kriterira Sangat Layak. Bahan ajar menyajikan gambar yang sesuai, ukuran huruf tepat, sajian informasi sistematis dilengkapi dengan latihan-latihan soal disertai kunci jawaban. Kode Braille yang ditampilkan dalam dua kolom beserta kombinasinya secara langsung memudahkan guru dalam menggunakan bahan ajar, sesuai pendapat Gargiulo (2006, p.498, Asep Hidayat dan Ate Suwandi, 2013, p.122). Hal ini sejalan dengan pendapat tentang desain pesan yang menggunakan urutan elaboratif dari mudah ke sulit dan dari umum ke rinci (Ulfah Hernaneny \& Edward Alfin, 2015, p.233).

Senada dengan hasil penelitian Elsayed, A.M (2015, p.862) bahwa penggunaan rangkaian urutan kompetensi dalam bahan ajar menampilkan informasi baru secara rinci terbukti efektif untuk belajar yang bermakna selama pendidikan terutama pengetahuan prosedural. Hal ini dikarenakan siswa memahami hubungan antara informasi dan melatih berpikir kritis seperti menginterpretasi, mengklasifikasi, mendiskriminasi, menyimpulkan dan menilai. Pada penelitian ini guru pendidikan khusus menginterpretasi urutan kompetensi-subkompetensi yang perlu dikuasai kemudian mengklasifikasi sesuai kode Braille dalam bahan ajar untuk kemudian melakukan diskriminasi.

Penggunaan bahan ajar berbasis teori elaborasi memiliki kelebihan dengan adanya simbolik pencerminan kode huruf, iconic dengan pembentukan huruf abjad utama menjadi "layar TV" dan penurunan letak titik huruf. Adanya ilustrasi gambar dan metode organisasi pesan yang tepat lebih memudahkan guru pendidikan khusus dalam mengahafal kode. Hal ini sesuai dengan pendapat Ratna Wilis Dahar (2011, p.53) bahwa penyusunan bahan ajar dengan elaborasi dan organisasi mampu 


\section{J PK (J urnal Pendidikan Khusus), 14 (2), 2018 - 54}

Rendy Roos Handoyo

memperlancar belajar dan menghafal karena adanya proses membentuk gambaran mental menggunakan analogi. Yan Xiung, Haliya, dkk (2014, p.9) menemukan hasil penelitian bahwa penggunaan elaborasi lebih baik pada pengetahuan prosedural dan kemampuan intelektual. Hasil penelitian Elsayed, A.M (2012, p.862) menunjukkan bahwa penggunaan analogi yang dikenal sesuai isi materi membuat siswa lebih mudah belajar tanpa kesalahpahaman. Analogi dengan suatu objek yang sudah dikenal berfungi sebagai jembatan untuk menghubungkan konseptual yang akan dipelajari dengan objek dikenal (Glynn, S, 2007, p.1, Itkonen, E, 2005, p.7). Di samping itu, Pivi Alpha Palomi dan Jailani (2015, p.69) menemukan hasil bahwa siswa belajar memotivasi diri, bertanggungjawab, percaya diri, menetapkan tujuan dan mengontrol perkembangan belajarnya ketika menggunakan analogi dalam belajar.

Chang, Y (2012, p.87) menemukan bahwa analogi sebagai inti dari kognisi, memainkan peran penting dalam aspek kehidupan termasuk pemecahan masalah, persepsi, memori, kreativitas, emosi dan komunikasi. Rickey, J.E, Philip, J.S dan Schun, C.D (2014, p.8) menemukan hasil bahwa terdapat hubungan antara analogi dengan kerja memori selama pelatihan. Fungsi analogi sebagai model mental untuk bentuk terbatas namun bermakna dalam pemahaman konsep yang kompleks. Penelitian Chang menunjukkan bahwa analogi memainkan peran dalam memori, artinya analogi yang digunakan oleh peneliti dalam bahan ajar membantu guru pendidikan khusus untuk mudah mengingat bentuk kode Braille.

Kemudahan guru pendidikan khusus dalam menghafal dan mengingat kode Braille karena adanya aspek spasial berupa pengelompokkan kode berdasarkan letak dan posisi titik. Hasil penelitian Musdaliha dan Nurdin Arsyad (2015, p.82) menunjukkan bahwa responden laki-laki menggunakan tata letak posisi objek lain dalam memahami konsep ruang. Responden wanita menggunakan tanda atau posisi sebagai patokan tanpa memperhatikan konsep keruangan. Walaupun terdapat perbedaan dalam penggunaan keruangan, namun responden tersebut bersama-sama menggunakan tanda atau posisi objek untuk mengingat.

Keuntungan penggunaan aspek visual spasial dalam pengelolaan materi karena dapat memanggil kejadian kembali dan diinterpretasikan untuk dapat melihat secara keseluruhan (Hindal, H.S: 2014, p.570). Hasil penelitian Brady, T; Konticle, T; Alvarez, G.A (2011, p.5) menemukan bahwa ketepatan penampilan perwakilan bagian objek sebagai kode membuat peningkatan signifikan dalam daya ingatan visual. Responden merespon berbagai kode untuk dikelompokkan menjadi objek yang sama sehingga mudah diingat. Spellman, T \& Rigolti, T, dkk (2015, p.313) menemukan bahwa penggunaan kombinasi kode dan perwakilan lokasi yang tepat dapat menguatkan daya ingat, ditunjukkan hasil gamma lebih besar pada bagian hippocampus bagian kerja memori. Hal ini didukung oleh penelitian (Ida Ayu Gede Bintang Praba Dewi dan Komang Rahayu Indrawati, 2014, p.247) bahwa pengelompokkan informasi yang diperoleh menguatkan makna dan asosiasi dalam ingatan sehingga otak bisa membentuk sebuah konsep.

Berdasarkan komentar yang diberikan oleh subjek uji coba, kecepatan dalam menghafal kode Braille didukung dengan adanya praktik langsung dalam latihan. Hal ini sesuai dengan cakupan yang perlu ada di dalam bahan ajar yakni petunjuk belajar bagi guru maupun siswa, kompetensi yang akan dicapai, informasi pendukung, latihan-latihan lembar kerja serta evaluasi, Andi Prastowo (2011, p.49). Kecepatan subjek dalam menghafal kode Braille menggunakan bahan ajar berbasis teori elaborasi memilki perbedaan. Walaupun berbeda, rata-rata subjek mempelajari bahan ajar selama 3 hari dengan 2,5 jam tiap harinya. Banyak kode yang dihafalkan rata-rata mencapai 13 kode. Perbedaan kecepatan dalam belajar dan menghafal kode Braille sesuai dengan kelebihan bahan ajar berbentuk buku. Atwi Suparman (2014, p.314) menyatakan bahwa salah satu kelebihan penggunaan bahan ajar cetak yakni pengguna atau pengguna dapat maju menurut kecepatan masing-masing.

\section{SIMPULAN}

Karakteristik produk yang dihasilkan yakni: a) bahan ajar menggunakan teori elaborasi untuk desain pengorganisasian pesan sehingga memberikan kemudahan bagi guru pendidikan khusus dalam menghafal kode Braille, b) bahan ajar yang dihasilkan memiliki bagian-bagian utama seperti sampul, identitas buku, glosarium, pendahuluan, peta kompetensi, isi materi, latihan soal, rangkuman dan identitas pengembang, c) bahan ajar dikemas dalam bentuk media cetak berupa buku berukuran A5 d) bahan ajar ini digunakan oleh guru pendidikan khusus di SLB maupun sekolah umum dalam menghafal kode, membaca dan menulis Braille serta pengajarannya bagi anak tunanetra. Kemudahan 


\section{J PK (J urnal Pendidikan Khusus), 14 (2), 2018 - 55}

Rendy Roos Handoyo

guru pendidikan khusus mempelajari bahan ajar karena terdapat unsur elaboratif seperti urutan rangkaian kompetensi, pesintesis, analogi dan pengaktif kognitif. Analogi dan pengaktif kognitif menggunakan kemampuan visual spasial untuk meningkatkan daya ingat dan kerja memori berdasarkan letak serta posisi titik kode Braille.

\section{DAFTAR PUSTAKA}

Andi Prastowo. (2012). Panduan Kreatif Membuat Bahan Ajar Inovatif. Yogyakarta: DIVA Press.

Asep Hidayat \& Ate Suwandi. (2013). Pendidikan Anak Berkebutuhan Khusus Tunanetra. Jakarta: PT. Luxima Metro Media.

Atwi Suparman. (2014).Desain Instruksional Modern, Panduan Para Pengajar dan Inovator Pendidikan Edisi Keempat. Jakarta: Erlangga.

Brady, T, Kontickle, T, Alvarez, G.A. (2011). A Review of Visual Memory Capacity: Beyond Individual Items and Toward Structured Representative. Jurnal. Journal of Vision 11 (5).

Bruner, J.S. (1960). The Process of Education. New York: Vintage Book

Chang, Y. (2012). On Rhetorical Function adn Structure Pattern of Analogy. Academy Publisher.

Chomsin Widodo. (2008). Panduan Menyusun Bahan Ajar Berbasis Kompetensi. Jakarta: PT. Elex Media Komutindo.

Elsayed, A.M. (2015). Effectiveness of Using Elaboration Theory in Teaching Mathematics to Develop Academic Achievement and Critical Thinking For Primary Students in Oman. Jurnal. International Journal of Humanities and Cultural Studies, Vol. 2, issue 3, December 2015, 851865.

Gargiulo, Richard. (2006). Special Education in Contemporarry Society. USA: Thompson Wasdworth.

Glynn, S. (2007). The Teaching With Analogies Models. Jurnal. Article NSTA

Harjanto. (2011). Perencanaan Pengajaran. Jakarta: Rineka Cipta

Hindal. H.S. (2014). Visual Satial Learning: A Characteristic of Gifted Students. Jurnal. Europian Scientific Journal. May, Vol. 10, No. 13 (557-574).

Http://www..nfb.org/brailleteacher, diakses pada tanggal 20 Maret 2017 pukul 10.45.

Ida Ayu Gede Bintang Praba Dewi, Komang Rahayu Indrawati. (2014). Perilaku Mencatat dan Kemampuan Memori Pada Proses Belajar. Jurnal. Jurnal Psikologi Udayana, Vol. 1 Nomor. 3

Itkonen, E. (2005). Analogy As A Structure And Process. Amsterdam: John Bejamines Publisher Company.

Lewis, R.B \& Doorlag, D.H. (2011). Teaching Student With Special Needs in General Education Classrooms. USA: Pearson

Made Wena. (2009). Strategi Pembelajaran Inovatif Kontemporer, Suatu Tinjauan Konseptual Operasional. Jakarta: PT. Bumi Aksara.

Merril \& Twitchell. (1994). Instructional Design Theory. USA: Educational Technology. 


\section{J PK (J urnal Pendidikan Khusus), 14 (2), 2018 - 56}

Rendy Roos Handoyo

Musdaliha, Nurdin Arsyad. (2015). Profil Kemampuan Spasial Dalam Menyelesaikan Masalah Geometris Siswa yang Memiliki Kecerdasan Logis Matematika Tinggi Ditinjau dari Perbedaan Gender. Jurnal. Jurnal Daya Matematis, Vol. 3 Nomor 1, Maret.

Pivi Alpha Palomi, Jailani. (2015). Pengaruh Pendekatan Analogi Personal Terhadap Prestasi, Penalaran dan Kemandirian Siswa Materi Dimensi di SMK. Jurnal. Phytagoras, Jurnal Pendidikan Matematika, Vol. 10 Nomor 1, Juni (61-70).

Puttman, B \& Tiger, F. (2015). Teaching Braille Lettes, Numerals, Punctuation and Contractions to Sighted Indiiduals. Jurnal. Journal of Applied Behaviour Analysis; Summer 2015; 48, 2: ProQuest.

Ratna Wilis Dahar. (2011). Teori-teori Belajar dan Pembelajaran. Jakarta: Erlangga

Rickey, J.E, Philip, J.S, Schunn, C.D. (2014). Is The Link Form Working memory to Analogy Causal? No Analogy improvements Following Working Memory Training Gains. Jurnal. Plososne, diakses pada www.plosone.org, Vol.9, September.

Sari Rudiyati. (2010). Pembelajaran Membaca dan Menulis Braille Permulaan Pada Anak Tunanetra. Jurnal. Jurnal Asesmen dan Intervensi Anak Berkebutuhan Khusus, Volume 9 Nomor 1 Juni.

Smith, M.K. (2010). Teori Pembelajaran dan Pengajaran. Jogjakarta: Mirza Media Pustaka.

Spellman, T, Rigolti, M, dkk. (2015). Hippocampus-Prefrontal Input support Spatial Encoding In working Memory. Jurnal. Macmillan Publisher Limited, Vol 5 No.22

Ulfah Hernaeny \& Edward Alfin. (2015). Pengaruh Strategi Pembelajaran Elaborasi Terhadap Hasil Belajar Matematika Ditinjau Dari Motivasi Belajar. Jurnal. Jurnal Formatif 5 (3):233-244.

Yan Xiung, Haiya Zahur, Ogilby, S.M. (2014). Eksperimental Investigation of The Effects of Cognitive Elaboration on Accounting Learning Outcomes. Jurnal. Journal of Education and Learning, Vol.3 no.4. 